\title{
SUSTAINABLE APPLICATION OF NATURAL GAS AS ENGINE FUEL IN CITY BUSES - BENEFIT AND RESTRICTIONS
}

\author{
Saša Milojević* \\ University of Kragujevac, Faculty of Engineering Science, Kragujevac, Serbia
}

Human activities, in particular transport, are partially responsible for the problem associated with the greenhouse effect, and therefore global warming. The transport sector is responsible for approximately $25 \%$ of carbon dioxide emissions and consumes almost $50 \%$ of global oil production. Natural gas as engine fuel has many advantages: lower costs, lower emissions because of more complete combustion, lower noise and longer engine life. The goal of the European Union is that alternative sources of energy represent $20 \%$ of total consumption by 2020 . According to the global strategy these problems are solving through a series of initiatives and innovations including the introduction of natural gas buses in city transport. If we take into account the existing situation in city transport, the strategic proposal is to begin by retrofitting diesel buses into dedicated natural gas vehicles. This paper analysed some benefits, which summarized according to the author's experiences about the introduction of the compressed natural gas buses in urban transport.

Key words: CNG buses, Natural gas, Emissivity, Transportation

\section{INTRODUCTION}

In the last 50 years, transport systems have been characterized by a serious increase in the use of the private car and the parallel development of road infrastructure and parking space to accommodate it. The following are some of the most adverse effects of this form of dispersed development based on a high use of the private car:

- congestion, and the related losses in travel time and competitiveness;

- higher transport costs for the community;

- loss of valuable green spaces;

- higher consumption of energy for passenger transport;

- pollution, and related health problems;

- contribution to climate change;

- decreased quality of urban life;

- health problems due to the lack of physical exercise; and,

- social exclusion for those who can't afford to live close to the city centres and do not have access to a private car.

In April 2010, the European Commission (EC) released a Communication on a European strategy on clean and energy efficient vehicles and fuels. EC set out several policy measures to support the creation of a clean and energy efficient transport system that will contribute to achieving the Europe 2020 objectives with respect to reduction of Carbon Dioxide $\left(\mathrm{CO}_{2}\right)$ emissions and increase the share of alternative fuels and renewable sources in transport [07].

Generally, transport is responsible for approx. $32 \%$ of the EU's final energy use and $21 \%$ of $\mathrm{CO}_{2}$ emissions. Public urban and sub-urban transport systems with buses are only responsible to a very low degree for local environmental pollution. As example, their energy consumption per travelled passenger kilometre is one-third of that of a car, specifically as the number of such vehicles involved is extremely low. As consequence, regarding to the total $\mathrm{CO}_{2}$ emissions, only $5 \%$ is generated by buses and coaches. Therefore, bus transport is not, in principle, an essential target in the fight against $\mathrm{CO}_{2}$ [07]. But because of the public nature of their activity, usually in close relation with or even regulated or funded by public bodies or authorities, bus operators have an extended responsibility in environmental matters. This means that the operators and the relevant authorities in this sector have to step up their commitment. 
Looking in the long term, new form of advanced propulsion systems (hybrid drive, fuel cells, etc.) will become widely accepted due to their low toxicity of exhaust gasses, specifically because of low noise emissions level. But while these advanced propulsion systems in vehicles do not reach the real price and the level of technical efficiency, there will be a strategic dilemma regarding the choice of powertrain and fuel. The ultimate goal is to meet increasingly strict environmental regulations and reduce fuel consumption.

Second option is the use of numerous alternative fuels existing as available for vehicles. EC action plan provides for a $20 \%$ substitution of conventional fuels such as petrol and diesel with alternative fuels by 2020 . The Commission aims at dramatically reducing Europe's dependence on imported oil and cut carbon emissions in transport by $60 \%$ based on 1990 levels by 2050. Methane (natural gas or biogas) is mentioned as one of the alternatives and can play an important role to help achieving the 2050 key goals. Methane will make an important contribution to achieve the predominant target to have no more conventionally fuelled cars in cities, in order to improve local air quality and reduce noise exposure. It will have to be complemented by the development of an appropriate refuelling infrastructure for new vehicles. Regarding to the global strategy, the large fleets of urban buses, taxis and delivery vans are particularly suitable for the introduction of alternative propulsion systems and fuels [07].

Compressed natural gas (CNG) and liquefied natural gas (LNG), both as the alternative fuels, have many advantages: lower cost, more complete combustion, lower emissions, lower noise and longer engine life. CNG technology has been developed for decades and now is available for commercial use in motor vehicles. Natural gas causing about $25 \%$ lower $\mathrm{CO}_{2}$ emissions compared to the same amount of energy diesel fuel, due to the lower carbon content $(\mathrm{H} \cdot \mathrm{C}-1=$ 4 ), and thus contributes significantly to reducing global warming. This enables bus body builders as example, to make natural gas buses comply with the challenging and voluntary emission standards, without using extensive filter technology as it is selective catalytic reduction system with Ad-Blue or expensive additives [01].

The introduction of natural gas powered vehicles is basically caused by very high investment costs that are required for the build-up of the needed refuelling infrastructure (CNG compressor's stations or LNG pumps). EU member states have decided to put a different strategy focus on national level, in terms of type of vehicles. As example, some states like France or Spain is so far mostly going for urban heavy duty vehicles (urban buses and trucks) using CNG, but hardly have any light duty vehicles on their roads [07].

According to previous, natural gas as fuel for motor vehicles has more and more share and like the consequences to this fact are that today world has approx. 22.5 million of natural gas vehicles (NGVs); (in Europe 1.76 million). In the Republic of Serbia, in traffic exist more than 880 NGVs $(90$ heavy duty vehicles, where is about 60 CNG powered buses and 800 cars and light duty vehicles). The number of CNG vehicle will be on the rise in Republic of Serbia, especially for public and private vehicles due to the introduction of CNG vehicles refuelling infrastructure [08].

The Republic of Serbia has initiated a number of projects at the local level in order to promote the ecological advantages of buses powered by CNG for the transport of passengers. The first example is the reconstruction of a diesel bus to drive on CNG in the city of Kragujevac, which is used for further development of lobbying in order to replace the entire diesel fleet with CNG buses $[02,03,05]$.

\section{CNG PROPULSION SYSTEM FOR CITY BUSES}

At the end of the nineties in the Republic of Serbia was attempting the production of city buses with CNG drive, where they used steel gas cylinders and natural gas engine complied with old technologies. Bearing in mind the experience of leading manufacturers of buses, the design engineers in domestics Production Company, have successfully implemented a prototype of fully low floor city bus with CNG propulsion system. The prototype bus is implemented with the original gas engine complied with (Euro IV) legislations, while the serial production continued with engines to meet the (EEV+) norm.

\section{Combustion concepts inside CNG engines main benefits}

Substituting conventional fuels (gasoline and diesel) by natural gas in road transport can be achieved by introducing to the market new vehicles ex-factory equipped with CNG engines, or as a first step, by converting engines of existing 
vehicles to CNG. To introduce natural gas as a fuel for road transport through the conversion of vehicles to CNG, the following options are possible:

a) modification of a gasoline (Otto) engine to CNG combustion (conversion to a dedicated fuel);

b) modification of a gasoline engine to either
CNG or gasoline (two way; bi-fuel) combustion;

c) conversion of a diesel engine to dedicated CNG (spark ignition) combustion; and,

d) conversion of a diesel engine to dual fuel (gas and diesel combined) combustion.

For conversion of existing diesel buses, only two options are applicable, Table 1 [01,07]:

Table 1: Natural gas engine combustion concepts - (Modification of diesel engine)

\begin{tabular}{|c|c|c|}
\hline $\begin{array}{c}\text { Combustion } \\
\text { concept }\end{array}$ & Dedicated spark-ignited (proposition) & Dual fuel \\
\hline $\begin{array}{l}\text { Combustion chamber } \\
\text { design, fuel injection } \\
\text { and air intake system }\end{array}$ & & \\
\hline Combustion system & $\begin{array}{l}\text { 1. gas and air pre-mixed at low } \\
\text { pressure; } \\
\text { 2. air flow is metered using a throttle; } \\
\text { 3. ignition from spark plug; } \\
\text { 4. uses either an oxidation catalyst or } \\
\text { three-way catalyst (lean or } \\
\text { stoichiometric mixture); } \\
\text { 5. Otto cycle. }\end{array}$ & $\begin{array}{l}\text { 1. gas and air pre-mixed at low pres- } \\
\text { sure; } \\
\text { 2. air may be partially metered using } \\
\text { a turbo air bypass or a throttle; } \\
\text { 3. ignition from diesel pilot injection } \\
\text { (existing injector or pilot injector); } \\
\text { and, } \\
\text { 4. Otto cycle or Diesel cycle. }\end{array}$ \\
\hline Fuel system & $\begin{array}{l}\text { 1. } 100 \% \text { natural gas; } \\
\text { 2. CNG or LNG; and, } \\
\text { 3. no run on diesel capability. }\end{array}$ & $\begin{array}{l}\text { 1. typical substitution of } 50 \text { up to } 60 \% \\
\text { over duty cycle; and, } \\
\text { 2. } 100 \% \text { run on diesel capable. }\end{array}$ \\
\hline
\end{tabular}

As example, for the retrofit, it is used spark ignited natural gas engine designed to meet 2010 U.S. Environmental Protection Agency (EPA) and California Air Resources Board (CARB) emission standards, Figure 1. The engine works on the base of stoichiometric combustion with cooled exhaust gas recirculation (CEGR) technology to enable a three way catalyst after treatment method, leveraging EGR technology to create a highperformance. With this engine and combustion concept, it is replaced the lean-burn technology used for first prototype bus engine. The cooled EGR system takes a measured quantity of exhaust gas and passes it through a cooler to reduce temperatures before mixing it with fuel and fresh air to charge the cylinder. Cooled EGR, in combination with stoichiometric combustion (the theoretical or ideal combustion process in which fuel and oxygen are completely consumed, with no unburned fuel or free oxygen in the exhaust), provides significant benefits $[01,10]$.

The use of cooled EGR (in place of large amounts of excess air used in lean burn technology) lowers combustion temperatures and knock tendency. Use stoichiometric combustion with CEGR technology also improves power density and fuel economy compared to lean and alone stoichiometric technologies. Compared to previous used lean burn natural gas engines, in this case, torque at idle is improved over $30 \%$ and fuel economy is improved by up to $5 \%[01,10]$. If we look from the point of using the buses in public transport, it is very important fact that selected stoichiometric engine type is capable of operating on CNG or LNG. The used engine can 
also operate on up to $100 \%$ bio methane, renewable natural gas made from biogas or landfill gas that has been upgraded to pipeline and vehicle fuel quality.

Another advantage is the fact that reconstructing buses from diesel fuel drive to CNG applications, it contributes to noise decline to a large extent. It was also proved during the conveyed tests and noise measuring according to methods defined by adequate and referential standards.

In public transportation of passengers in the city of Kragujevac there are 50 buses which daily make about $250 \mathrm{~km}$ as an average (315 working days per year). By applying CNG buses instead of the existing with diesel engines, a considerable decline in noise emission would be achieved.

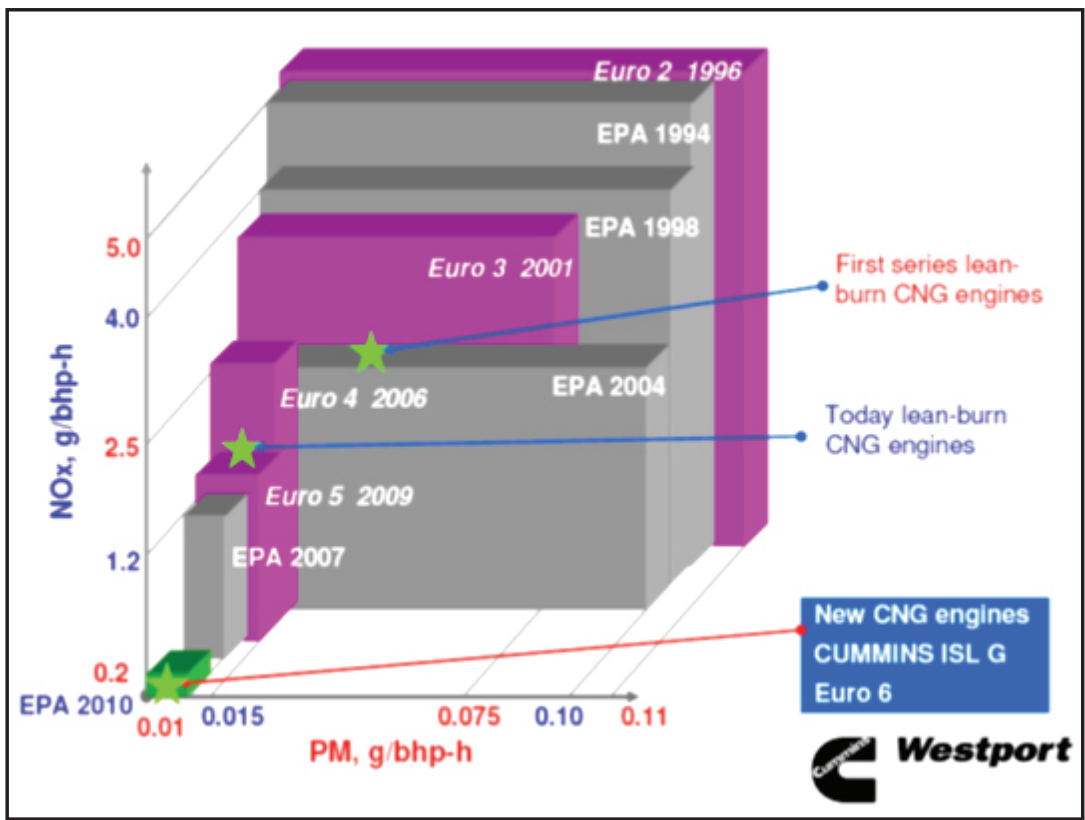

Figure 1: Exhaust gas emission standards and used engines position

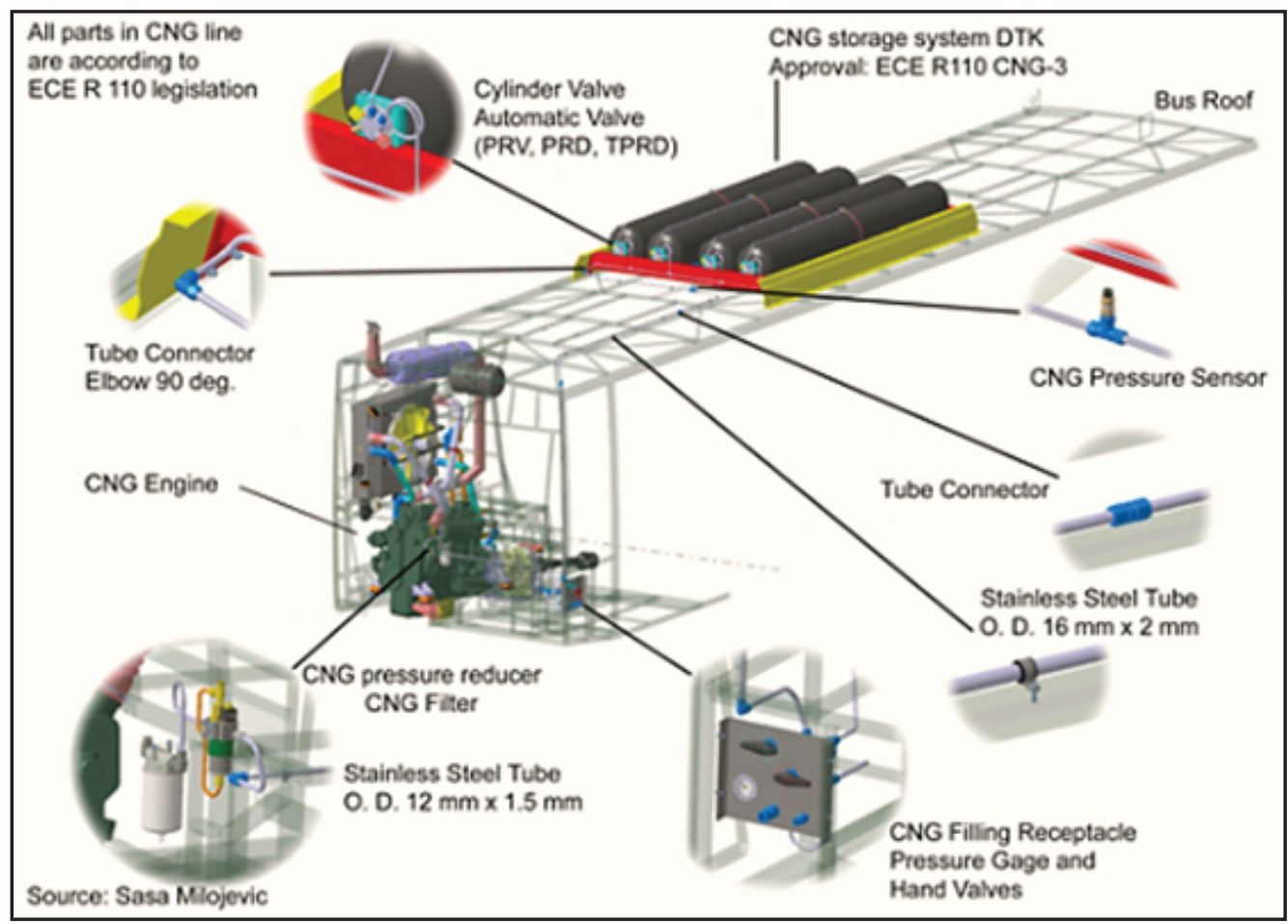

Figure 2: Ketch of the CNG fuel line equipment installed on the bus 


\section{Proposed system for supply of CNG}

Figure 2, shows parts of the installation for CNG supply from bus roof mounted gas cylinders to the engine that is applied to prototype version of CNG bus. All parts inside of the CNG installations are designed and approved according to the UN ECE Regulation No. 110 [02,05,06,09].

The retrofit of the diesel bus into dedicated natural gas vehicle begins with the joining of the CNG cylinders with the original rack, Figure 2, to the bus roof. It is selected storage system for CNG that includes (type III) cylinders composed of (Al 6061) liner reinforced by carbon fibre in epoxy resin (brand Dynecell(), with a favourable ratio between weight and volume $(0.3$ to $0.4 \mathrm{~kg} \cdot \mathrm{l}-1)[02,04]$.

According to requirements for vehicles of categories M3 and N3, (resistance to destruction of the roof structure during deceleration of $(6.6 \cdot \mathrm{g})$ in longitudinal and $(5 \cdot \mathrm{g})$ in transverse direction), it is calculated and accepted the mounting of CNG cylinders assembly to carry through the auxiliary "U" profiles. The position of the new centre of gravity is calculated, taking into account the added weight of the CNG cylinders with the rack on the bus roof $[02,06,09]$.

\section{SAFETY GUIDELINES RELATED TO CNG BUSES}

The relevant properties of natural gas which are important to know when used as vehicle fuel are:

- it is non-toxic, neither carcinogenic nor corrosive gas, but it is the stuffy;

- natural gas is invisible but must been odorized so its presence can be detected;

- unlike gasoline vapours, natural gas is lighter than air (methane has density of $0.68 \mathrm{~kg} \cdot \mathrm{m}^{-3}$ at $15^{\circ} \mathrm{C}$ ) and it is in the gaseous form at atmospheric conditions. In an event of a leak, this property allows to quickly rise and disperse in the atmosphere, while the propane $\left(1.87 \mathrm{~kg} \cdot \mathrm{m}^{-3}\right)$ and butane $\left(2.44 \mathrm{~kg} \cdot \mathrm{m}^{-3}\right)$ are heavy than air, and lower to floor;

- Natural gas has an auto ignition temperature of approx. (480 to $650{ }^{\circ} \mathrm{C}$ ) whereas gasoline is approx. (260 to $430{ }^{\circ} \mathrm{C}$ ) and diesel less than $\left(260{ }^{\circ} \mathrm{C}\right)$. This relatively high auto ignition temperature for CNG is an additional safety feature of this fuel; and,

- Methane has a very selective and narrow range of flammability. The mixture of gas in air by volume that will support combustion is between (4.4 and 15\%). In other words, with less than $(4.4 \%)$, of the methane in air, the mixture will not burn because it is too lean, and with greater than (15\%), the mixture is too rich and will not burn. Ignitable range for gasoline is between (1.4 and 7.6\%) and around $(0.6$ to $7.5 \%)$ for diesel.

The main safety concern regarding CNG buses in a repair facility is the possibility of fuel releases and their consequences. Natural gas leaks can be either fast or slow. A fast leak usually involves the release of a safety valve or complete severing of a fuel line. In the case of the safety valve, all the gas in the fuel cylinder will be vented to the atmosphere. Other major fuel releases can be controlled by closing appropriate valves. Slow releases are caused by fuel escaping through a loose fitting or an abraded line or hose.

Both types of leaks can cause flammable mixtures to form in the work area. These flammable mixtures will disperse and over time will dissipate to safe levels. Workplace safety can be maintained by reducing fuel release volumes, keeping ignition sources away from areas where flammable mixtures may travel and using proper ventilation to control how long these flammable mixtures exist and where they will be present.

If a slow fuel release occurs, natural mixing of the released fuel with the surrounding air will cause most such mixtures to become too lean to support combustion. Methane's relatively narrow flammability range means that the diluting of the mixture occurs quickly and the only flammable mixture will be near the release site.

Methane is lighter than air, and released fuel will tend to rise from the release site. This contrasts with conventional fuels which puddle and form vapours that travel along the floor. In facilities where CNG buses are being serviced, ignition sources above the vehicles are of primary concern. These ignition sources can include electric equipment that generate sparks or high surface temperatures and open flame heaters. Ventilation systems should be designed to remove fuel from above vehicles or to promote mixing of the air in the space above the vehicles.

We insist on the obligatory equipment of the buses with system for fire-extinguishing with water mist in engine compartment and other enclosed spaces. 


\section{BENEFIT OF CNG BUSES - EXAMPLE KRAGUJEVAC CITY}

By using buses with CNG drive, primarily to a large extent contribute to the preservation of health; as compared to conventional diesel vehicles have the following environmental benefits [10]:

- meets regulated 2010 EPA/CARB and Euro VI (09.2014) limits for emissions;

- lower greenhouse gas emissions (up to $25 \%$ less);

- improved reliability and engine efficiency;
- reduced reliance on crude oil;

- bio-methane capable and pathway to hydrogen;

- natural gas is safer than existing liquid fuels;

- CNG costs up to $50 \%$ less than gasoline or diesel fuel; and,

- it can be transported anywhere.

Cost-benefit analysis regarding to the public transportation of passengers with CNG and diesel buses 315 working days per year is presented inside of Table 2.

Table 2: Costs Analysis regarding to the situation with diesel or CNG propulsion system

\begin{tabular}{|c|c|c|c|}
\hline Comparative parameters & Diesel bus type 203 & $\begin{array}{c}\text { Gas bus } \\
\text { type } 203 \mathrm{CNG}-\mathrm{S}\end{array}$ & Saving \\
\hline Fuel price & $1.3 € \cdot \mathrm{I}^{-1}$ & $\begin{array}{c}0.45 € \cdot \mathrm{kg}^{-1 *} \\
0.8 € \cdot \mathrm{kg}^{-1 * *}\end{array}$ & $/$ \\
\hline $\begin{array}{c}\text { Average fuel } \\
\text { consumption } \\
\text { (Measured per one bus) }\end{array}$ & $40 \mathrm{I} /(100 \mathrm{~km})$ & $33 \mathrm{~kg} /(100 \mathrm{~km})$ & $/$ \\
\hline $\begin{array}{c}\text { Fuel consumption for one } \\
\text { year }\end{array}$ & $1,746,000 \mathrm{I}$ & $1,455,300 \mathrm{~kg}$ & $/$ \\
\hline $\begin{array}{c}\text { Fuel costs for one year } \\
\text { (for 50 buses in city } \\
\text { transport) }\end{array}$ & $2,293,200 €$ & $\begin{array}{c}645,855 €^{*} \\
1,164,240 €^{* *}\end{array}$ & $\begin{array}{c}1,647,315 €^{*} \\
(\text { Saving of min. } 50 \%)\end{array}$ \\
\hline
\end{tabular}

${ }^{*}$ The case with proper refuelling station; ${ }^{* *}$ the case with public refuelling station.

\section{GAS MARKET SUPPLY AND CNG BUSES FILLING - ONE OF RESTRICTIONS}

The security of the CNG supply is very important requirement to continue the introductions of natural gas vehicles in city transport.
According to previous, to secure natural gas supply to the transporters and another, like the bridge before gas networking (applicable for any territories), is better to use the containers for CNG bulk transport with trailers, as it is demonstrated on the Figure 3 [04].
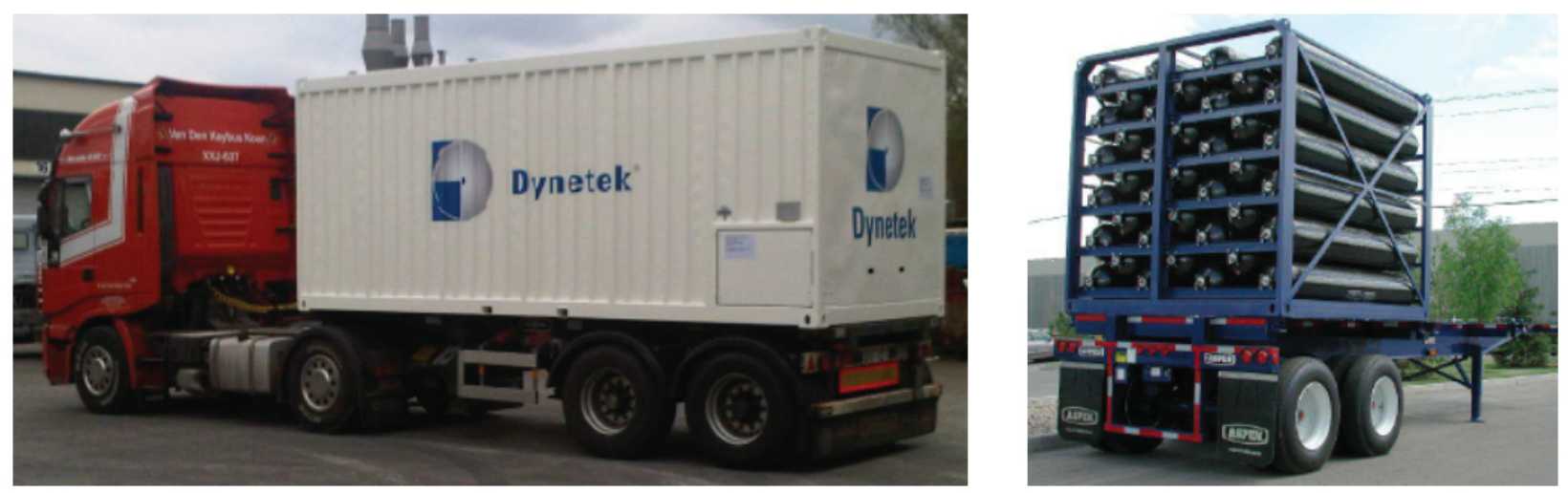

a) ISO $20 \mathrm{ft}$. container

(b) $10 \mathrm{ft}$. cube for bulk transport

Figure 3: Containers for CNG bulk transport (250 bar modules) 
Analysed containers for gas transport are approved according to ADR as MEGC, with the next main characteristics [4]:

- extremely high storage capacity due to lightweight composite cylinders;

- low weight, less wear and friction resulting in lower costs for maintenance and repair;

- handling by crane or forklift;
- lifetime up to 40 years;

- standard 250 bar service pressure; and,

- vertical or horizontal assembly with neck or belly mounting cylinders.

The comparison between composite (type III) cylinders and steel cylinders with dimensions and filling characteristics and capacities, are presented in Table 3 [04].

Table 3: Technical dates of buses tested comparatively

\begin{tabular}{|c|c|c|c|}
\hline Type of CNG container & $20 \mathrm{ft}$. container & $40 \mathrm{ft}$. container & $\begin{array}{l}\text { Jumbo vessels } \\
40 \mathrm{ft} . \text { semitrailer }\end{array}$ \\
\hline Cylinder material & $\begin{array}{r}\text { Composi } \\
\text { Al } 6061 \text { liner with carl }\end{array}$ & $\begin{array}{l}\text { type III) } \\
\text { fibre in epoxy resin }\end{array}$ & Steel 34CrMo4 \\
\hline Standard & \multicolumn{3}{|c|}{ TPED / ADR } \\
\hline Number of cylinders & 76 & 152 & 9 \\
\hline Cylinder outside diameter & \multicolumn{2}{|c|}{$406 \mathrm{~mm}$} & $559 \mathrm{~mm}$ \\
\hline $\begin{array}{l}\text { Weight / volume ratio } \\
\text { (per one cylinder) }\end{array}$ & \multicolumn{2}{|c|}{$84 \mathrm{~kg} /(234 \mathrm{l})$} & $2660 \mathrm{~kg} /(2385 \mathrm{I})$ \\
\hline $\begin{array}{l}\text { CNG capacity* / cylinder } \\
\text { volume ratio (total) }\end{array}$ & 4222 kg / (17784 I) & 8444 kg / (35568 I) & $4471 \mathrm{~kg} /(21400 \mathrm{l})$ \\
\hline $\begin{array}{l}\text { Cylinders weight / container } \\
\text { weight ratio (for full system) }\end{array}$ & $6384 \mathrm{~kg} /(15 \mathrm{t})$ & 12768 kg / (29.4 t) & $23940 \mathrm{~kg} /(40 \mathrm{t})$ \\
\hline Working / test pressure & \multicolumn{2}{|c|}{$250 /$ ( 375 bar) } & 250 / (300 bar) \\
\hline
\end{tabular}

*Depending on actual density of CNG and filling conditions.

TPED-Transportable pressure equipment directive; ADR-European agreement concerning the international carriage of dangerous goods by road; MEGC-Multi element gas container.

\section{CONCLUSIONS}

Use of CNG as an alternative fuel is an effective, currently available way to help solve environmental and fuel resource problems. In fact, natural gas has safety advantages compared to gasoline and diesel: it is non-toxic, neither carcinogenic nor corrosive gas, and has no potential for ground or water contamination in the event of fuel release.

Substituting existing fuels by natural gas in road transport can be achieved by introducing new vehicles equipped with CNG engines, or as a first step, by converting engines of existing vehicles to CNG drive. The better variant for buses is the using of the completely new engine with dedicated CNG combustion.

The introduction or expansion of natural gas vehicles use will require investment in new refuelling infrastructure. To secure natural gas supply to the transporters and another, like the bridge before gas networking is better to use the Containers for CNG Bulk transport with trucks and trailers.

When deciding to introduce or expand the use of CNG buses, one must evaluate the appropriate CNG engine technology to use relative to the desired emissions performance. Current lean-burn CNG engine technology can only achieve Euro $V$ emissions levels with the addition of oxidation catalyst. To achieve U.S. 2010 or Euro VI emissions performance stoichiometric CNG engines with three-way catalyst will be required.

By installing the gas rack with CNG cylinders (type III) and with projecting the installation of CNG equipment of the bus according to the UN ECE Regulation No. 110, was achieved great progress from the aspect of vehicle safety in traffic.

During the prototype bus exploitation it was confirmed a better fuel economy with CNG, com- 
pared to diesel drive. Fuel cost per kilometre is lower for about two or three times with CNG regarding to diesel power, specifically in situations than the transportation company has its properly CNG fuel station.

\section{REFERENCES}

1) Hoffman, K., Benz, M., Weirich, M., Herrmann, H. O., (2014). The new MercedesBenz medium duty commercial natural gas engine. MTZ worldwide, 75, 11, 4-10.

2) Milojevic, S. and Pesic, R., (2012). Theoretical and experimental analysis of a CNG cylinder rack connection to a bus roof. Int.J Automot. Technol.13, 3, 497-503. doi:10.1007/s12239012-0047-y

3) Živanović, Z., Petković, S., Mišanović, S., Holo, A., Šakota, Ž., (2015). Natural Gas Buses in Serbian Public Transport - Some Operational Experiences. FME Transactions, 43, 2, 89-98.

4) Milojević, S., (2016). Reconstruction of existing city buses on diesel fuel for drive on hydrogen. Applied Engineering Letters, 1, 1, 16-23.
5) Milojevic, S. and Pesic, R. (2011). CNG buses for clean and economical city transport. Int. J. Vehicle Mech., Engines and Transportation Syst. 37, 4, 57-71.

6) Kojic, M., Slavkovic, R., Zivkovic, M., Grujovic, N., (1998). Finite Element Method I Linear Analysis, (in Serbian), Faculty of Mechanical Engineering, Kragujevac.

7) http://www.ngvjournal.com/worldwide-ngvstatistics, retrieved on November 1st, 2016.

8) http://www.unece.org/fileadmin/DAM/trans/ main/wp29/wp29regs/updates/R110r3e.pdf, retrieved on August 31th, 2016.

9) https://www.dieselnet.com/standards/eu/ hd.php, retrieved on November 1st, 2016.

10) https://www.ngva.eu/downloads/news/ 2012 \%20Final\%20IGU\%20UN\%20ECE\%20NG V\%20Report\%202012.pdf, retrieved on August $31^{\text {th, }} 2016$.

Paper sent to revision: 11.02.2016.

Paper ready for publication: 15.03.2017. 